\title{
USING CARDS IN LEARNING ENGLISH VOCABULARY TO YOUNG LEARNERS
}

\author{
Derin Karbala \\ derinkarbala@gmail.com
}

\begin{abstract}
The paper targets clarifying how essential young learners are shown vocabulary through Alphabet Cards. The subject of this homeroom activity research was 20 youthful students. The examination was a study hall activity research which was directed in two cycles where each cycle comprised of preparation, execution, perception and reflection. The information of this examination was acquired from the consequences of the test and perception sheet, survey, field notes, during the execution of the activity. The discoveries of the examination showed that Alphabet Cards was powerful in creating essential youthful students' vocabulary. The adequacy of Alphabet Cards was appeared by the improvement of youthful students' score. The discoveries uncovered that in cycle 1 there were 20 young learners who accomplished least standards of accomplishment. It implies that the traditional accomplishment was $40 \%$. In cycle 2 , it showed that there were 42 of 50 young learners who accomplished the base rules of accomplishment. It implies that the addition accomplishment was $84 \%$. Gain accomplishment depends on the quantity of young learners who get the score in any event the standards of achievement (70). Both of the acquired and individual accomplishments have met the rules of achievement. It tends to be inferred that the Alphabet cards is compelling to build up the youthful students' vocabulary.
\end{abstract}

Keywords: Vocabulary, Alphabet Cards, young learners

\section{INTRODUCTION}

To prepare young learners to bestow in a language, they ought to rule the vocabulary of the language. Vocabulary is fundamental in language learning and it ought to be learned by youthful students. It is the reason of the language, in English just as in various vernaculars. Vocabulary authority of the young learners can assist them with passing on by using this language (Přibilová, 2006; Rolando, 2003; Bakhsh , 2016; Santiana and Fatimah, 2017; Marzuki, 2019b).

In teaching and learning practices for school youthful students, some training media can be used: like tune, games, puzzle-word, pictures, word onceover of card, and Alphabet card. These media can help the teacher with training 
young learners to overwhelm the English vocabulary (Harmer, 1998; Lang and Nunan, 2006; Berne and Blachowicz, 2008; Destianingsih and Satria, 2017; Marzuki et al., 2018; Fatimah et al., 2019; Lelawati et al., 2019; Marzuki, 2019a; Alek et al., 2020). Numerous young learners have low capacity in vocabulary particularly for school youthful students. Despite the fact that, they have effectively examined English in Elementary School level. The young learners got hard to recollect the vocabulary (Marzuki, 2017; Marzuki, 2019c; Alek et al., 2020; Albana et al., 2020; Kuliahana and Marzuki, 2020). The absence of vocabulary may get from both young learners as the students and the educator as the teacher. Youthful students' powerlessness in remembering various words make them hard to learn English. While educator's failure to pick a decent procedure make the instructor hard to clarify material for youthful students. In this way young learners need one procedure to build their vocabulary like Alphabet cards.

The specialist picked the investigation test since she found that the young learners got hard to recall the vocabulary. The shortfall of vocabulary may get from the two young learners as the young learners and the instructor as the educator. Youthful students' weakness in holding different words make them difficult to learn English. While teacher's inability to pick a respectable technique make the instructor difficult to explain material for youthful students. Considering the troublesome statement, the specialist made it more careful on the target of depiction, the expert point by point in research address as follow:

How does Alphabet Cards in Teaching Vocabulary to the essential youthful students?

\section{RESEARCH METHOD}

The arrangement of this investigation was CAR (Classroom Action Research). As demonstrated by Kemmis and McTaggart, Classroom Action Research proposes the scientist to have an aggregate movement. Movement research is local area; it remembers those reliable for improving it, augmenting the collaborating bundle from those most directly improved to anyway numerous as could be permitted of those impacted by the preparation concerned. This investigation required the analyst and her accomplice plan practice plans, prepare 
instructional material and media, and complete the action plan. To coordinate the investigation, the scientist and her accomplice began the assessment from orchestrating, completing, seeing, and reflecting. The four essential activities were called stages (Kemmis and McTaggart, 1988; McNiff, 1992; Marzuki, 2016).

\section{Results and Discussion}

\section{Student's Participation in Teaching Learning Process}

Evaluation on training learning connection should be exhaustively driven by the scientist to enable the educator to coordinate a careful judgment about the cycle. Widely inclusive assessment consolidates the evaluation stresses over youthful students' participation in homeroom joint effort. Youthful students' help ought to be assessed to guarantee that they are esteemed each time they set forth a brave exertion. Identified with examination on youthful students' premium, youthful students' interest in the empowering learning cycle can be assessed by using gave charts. Obviously to overview or to survey youthful students' participation adds to reduce their disquiet to practice or any extremely obfuscated homeroom task. To study youthful students' examination lobby support, the scientist used insight plan that contains five saw things: excitement, motivation, interest, response, and progress. Those things were seen and overviewed by the accomplice.

\section{Student's Performance in Teaching Learning Process}

Youthful students' introduction in the training learning measure was tended to by five fragments in which the young learners were reviewed. It was by reason masterminded by the analyst to see the qualification in youthful students' introduction starting with one assembling then onto the next. Undeniably to overview or to evaluate youthful students' show adds to reducing their apprehension to practice or any extremely bewildered examination corridor task.

The parts that the examiner used them as pointers to assess youthful students' display in the educating learning measure are understudy's energy, motivation, premium, response, and youthful students' progression. The five portions were purposely seen to guarantee that the young learners have progress in investigation corridor execution from one social event to other get-together. 
The eventual outcome of the assessment toward youthful students' homeroom execution will be explained as follows: (1) Young students' energy toward the showing learning measure in (a) most of the understudy in social occasion 1 and 2 cycle I were in focus class; (b) by far most of the understudy in get-together 3 cycle I were in high grouping, (c) meeting 1, 2, and 3 cycle II were in high characterization. From the data presentation, it will in general be assumed that the young learners have an improvement to the extent their energy when they were in the resulting social affair; and they could stay on the improvement up to meeting 3. It is a consequence of the expert's treatment where she explained the task or gave direction using English, the educator expected to uncover it in Indonesian to thwart to young learners misinterpreting the information given.

(2) The examination on youthful students' motivation shows that (a) meeting 1,2 , and 3 cycle I were in focus class; (b) meeting 1 and 3 cycle II were in focus order; (c) meeting 2 cycle II were in fashionable. From the portrayal, it will in general be unraveled that the young learners were energized to join the class. They battled to stand sufficiently apart to be seen to be offered undertaking to wrap up. (3) The finding stresses with understudy's benefit explains that assembling (a) 1, 2, and 3 cycle I were in focus class; (b) meeting 1, 2, and 3, cycle II were in high order. The revelations related to youthful students' benefit all through homeroom social events uncover a differentiation. If the young learners were in the middle class concerning their benefit in the essential cycle; it isn't equivalent to the ensuing cycle. Since the expert found that there was any basic headway in interest when they were in the resulting cycle. (4) Young students' response toward the training learning measure was one of the parts that the specialist saw during showing learning measure. The result of insight shows that (a) meeting 1 cycle $I$ is in low order; (b) meeting 2, and 3 cycle I were in focus characterization; (c) meeting 1 and 2 cycle II were in focus class; and (d) meeting 3 cycle II were in high grouping. It had all the earmarks of being that the young learners didn't have any unconstrained response toward educator's direction, given exercise until they were in the second assembling of cycle I. They achieved fashionable stressed to response when they were at meeting 3 cycle II. The expert 
sees that such advancement is requested lazy. (5) It was found that understudy's progression changed starting with one assembling then onto the next; meeting 1 cycle I is in low order; (b) meeting 2 and 3 cycle I were in focus grouping; (c) meeting 1 and 2 cycle II were in focus arrangement; and (d) meeting 3 cycle II were in fashionable. From the depiction over, the result of assessment can be contemplated that the young learners achieved the pick of progress when they were in the second assembling of cycle I. It is an immediate consequence of the scientist's treatment on giving greater freedom to the young learners for asking clarification when they really don't see yet about the task.

\section{Young learners' improvement (Meetings 1, 2, and 3, in cycle I)}

To take a gander at the three standards of achievement, the scientist used Alphabet cards, insight enrollment, and field notes. The postponed outcome of assessment was that from the fundamental primer of the cycle 1 it was found there were ten of 50 young learners who got "unimaginable" score and four young learners who got "splendid" score. It surmised that the youthful students' beneficial rate that got achievement level from the fundamental primer of cycle I had not currently meet the models of accomplishment. Since, the rate approach utilized equation $20 \times 100 \%: 50=60 \% .20$ was the measure of young learners who got achievement capacity; 50 was the sum, considering everything, and 100 is the deviation scale. Then again, the level of study anteroom achievement ought to be $70 \%$ of the measure of youthful students.

By then, the score of fourteen young learners were more than 70 . It was not agent enough for the master to presume that the norms of progress have been refined since the models of achievement for specific young learners ought to be 70. Hence, close to the day's end, the master combat the models of progress will be refined if a large portion of young learners accomplish score 70 or over it and there are at any rate $70 \%$ from through and through young learners got achievement level. Moreover, single score regardless was to denounce the youthful students' accomplishment as it were. There a few reasons why the young learners couldn't appear at the standards of achievement in cycle I, to be unequivocal: the master didn't clarify the guidelines until the entire of the young 
learners see well, even she offered opportunity to the young learners for asking explanation yet the possibility was not cover all young learners who required the explanation.

The youthful students' premium in learning measure was perceived through assessment hall works out. Premium as such a learning measure was investigated inwardly. The aftereffect of understanding shows that the young learners were suitably looking at examination passage works out.

\section{Meetings 1, 2, and 3 in cycle 2}

The eventual outcome of examination toward appraisal on cycle II social occasion 3 evoked the basic progression on youthful students' vocabulary. During that time test in cycle II; it was found that there were 42 young learners who got "accomplishment" capacity. It suggests that the amount of young learners who got "accomplishment" from the second evaluation of cycle II has met the guidelines of progress; considering the way that the rate approach uses formula $42 \times 100 \%: 50=84 \% .42$ is the amount of young learners who get "accomplishment" ability; 50 is the amount, things being what they are, and 100 is the deviation scale. Since the amount of young learners who got "accomplishment" capacity more than a bit of the total number of young learners ( $84 \%)$, so it is contemplated that the proportions of homeroom achievement has been cultivated.

Meanwhile the higher score of 42 young learners more than 70. It will in general be unraveled that it is absolutely reasonable for the specialist to conclude that the models of achievement have been cultivated since the proportions of accomplishment for solitary young learners should be 70; moreover there were 42 young learners who got at any rate 70 so the number has tended to all class individuals.

There are a couple of reasons why the young learners could show up at the proportions of achievement in cycle II, specifically:

1. The specialist set the time moderately for all of the activities done.

2. When asking the young learners for turn, the teacher should permit to explicit young learners just as others young learners generally. 
3. In explaining the task or giving direction using English, the teacher revealed it in Indonesian to hinder to young learners misjudging the information given.

\section{CONCLUSIONS}

Considering the delayed consequence of this homeroom action research, the expert shut as follows: By completing the Alphabet cards technique, the young learners were not difficulty to review vocabulary given. We could discover in the chief test, the youthful students' improvement showed up at $40 \%$ of 20 youthful students. Meanwhile, in the resulting test, youthful students' improvement achieved $84 \%$ of 42 youthful students. The educating learning practices that were used in this methodology had the alternative to make understudy' energy, motivation, premium, response, and progress in joining the class.

\section{REFERENCES}

Albana, H., Marzuki, A. G., Alek, A., \& Hidayat, D. N. (2020). Cohesive Devices in Student's Writing (A Discourse Analysis on Argumentative Text). Jurnal Pendidikan Humaniora, 8(1), 6-11.

Alek, A., Marzuki, A. G., Farkhan, M., \& Deni, R. (2020). Self-Assessment in Exploring EFL Young learners' Speaking Skill. Al-Ta lim Journal, 27(2), 208-214.

Alek, A., Marzuki, A. G., Farkhan, M., Surahman, D., Daryanto, D., \& Febrianto, S. (2020). Computer Based Testing in Senior High School on National Examination. Indonesian Journal of Learning Education and Counseling, 2(2), 204-210.

Bakhsh, S. A. (2016). Using Games as a Tool in Teaching Vocabulary to Young Learners. English language teaching, 9(7), 120-128.

Berne, J. I., \& Blachowicz, C. L. (2008). What reading teachers say about vocabulary instruction: Voices from the classroom. The reading teacher, 62(4), 314-323.

Butler, Y. G. (2019). Teaching vocabulary to young second-or foreign-language learners: What can we learn from the research?. Language Teaching for Young Learners, 1(1), 4-33.

Demircioğlu, Ş. (2010). Teaching English vocabulary to young learners via drama. Procedia-Social and Behavioral Sciences, 2(2), 439-443.

Destianingsih, A., \& Satria, A. (2017). A study on the effectiveness of using alphabet cards game in teaching vocabulary for commercial business administration young learners. In UAD TEFL International Conference (Vol. 1, pp. 54-64).

Fatimah, A. S., Santiana, S., \& Saputra, Y. (2019). Digital Comic: An Innovation of Using Toondoo As Media Technology for Teaching English Short Story. English Review: Journal of English Education, 7(2), 101-108. 
Harmer, J. 1998. How to Teach English. Cambridge. Pearson Longman

Kemmis, S. and McTaggart, R. 1988. The Action Research Planer. Australia. Deakin University.

Kuliahana, A., \& Marzuki, A. G. (2020). Repetition Technique in an EFL Speaking Class in Islamic Higher Education in Indonesia. Academic Journal Perspective: Education, Language, and Literature, 8(1), 20-28.

Lang, H. R. and Nunan, D. 2006. Models, Strategies, and Methods for Effective Teaching. United States. Pearson.

Lelawati, S., Dhiya, S., \& Mailani, P. N. (2019). The teaching of English vocabulary to young learners. PROJECT (Professional Journal of English Education), 1(2), 95-100.

Marzuki, A. G. (2019a). The Implementation of SQ3R Method to Develop Young learners' Reading Skill on Islamic Texts in EFL Class in Indonesia. Register Journal, 12(1), 49-61.

Marzuki, A. G. (2019b). The Roles of School Principal Leadership in Developing English Teachers' Creativities in Palu. Al-Ta lim Journal, 26(3), 267-279.

Marzuki, A. G. (2019c). Utilizing Recorded English Dialogues in Teaching English Word Stress to Islamic Higher Education Young learners in Indonesia. Jurnal Pendidikan Islam, 5(1), 53-64.

Marzuki, A. G., Alim, N., \& Wekke, I. S. (2018). Improving the reading comprehension through cognitive reading strategies in language class of coastal area in indonesia. In IOP Conference Series: Earth and Environmental Science, 156(1), 012050). IOP Publishing.

Marzuki, A.G. (2016). Utilizing cooperative learning in islamic college young learners' classroom, IJEE (Indonesian Journal of English Education), 3(2), 123-139.

Marzuki, A.G. (2017). Developing speaking skill through oral report in an efl class in indonesia, Al-Ta'lim Journal, 24(3), 243-254.

McNiff, J. 1992. Action Research: Principle and Practice. New York. Chapman and Halls.

Přibilová, L. (2006). Teaching vocabulary to young learners (Doctoral dissertation, Masarykova univerzita, Pedagogická fakulta).

Rolando, M. 2003. Teaching your Kids through Alphabet Cards. (Online) http://www.reading-with kids.com/Alphabet Cards.html, accessed on April 2, 2011.

Santiana, S., \& Fatimah, A. S. (2017). Prezi, Cloud-Based Presentation, for Teaching: How is it Interesting?. EduLite: Journal of English Education, Literature and Culture, 2(2), 445-456. 